\title{
HUBUNGAN KEPEMIMPINAN DENGAN MUTU PEMBELAJARAN
}

\author{
Rabukit Damanik \\ Dosen STKIP Budi Daya Binjai
}

\begin{abstract}
Abstrak
Peningkatan mutu pendidikan nasional telah dilakukan dengan perbaikan kurikulum, peningkatan mutu guru, penyediaan sarana prasarana, perbaikan kesejahteraan guru, perbaikan manajemen, pengawasan dan perundang-undangan. Guru yang profesional dan handal akan mengetahui manajemen kelas dengan baik guna mengelola proses pembelajaran yang pada akhirnya akan meningkatkan mutu pembelajaran. Tujuan penelitian ini adalah: untuk mengetahui hubungan kepemimpinan dengan mutu pembelajaran; Metode penelitian ini adalah penelitian kuantitatif korelasi. Sampel adalah guru SMA Rayon 3 Medan yang berjumlah 67 orang. Hasil Penelitian menunjukkan terdapat hubungan yang signifikan antara kepemimpinan dengan mutu pembelajaran. Koefisien Korelasi yang diperoleh adalah 0,604 dengan level signifikansi alpha sebesar 0,05 .
\end{abstract}

\section{Kata Kunci : Kepemimpinan dan Mutu Pembelajaran}

\section{A. Pendahuluan}

Pendidikan yang bermutu selalu menjadi harapan bagi setiap bangsa, baik yang di selenggarakan oleh pemerintah maupun masyarakat. Zamroni (2007:2) mengatakan bahwa peningkatan mutu sekolah adalah suatu proses yang sistematis yang terus menerus meningkatkan kualitas proses belajar mengajar dan faktor-faktor yang berkaitan dengan itu, dengan tujuan agar target sekolah dapat tercapai dengan lebih efektif dan efisien. Masalah pendidikan di Indonesia saat ini masih seputar rendahnya kualitas, relevansi, efisiensi dan produktifitas serta efektifitas. Penyebabnya adalah: (1) ketersediaan pendidik dan tenaga kependidikan yang belum memadai baik secara kuantitas maupun kualitas, (2) kesejahteraan pendidik yang belum memadai, (3) sarana dan prasarana yang kurang dan belum didayagunakan secara optimal, (4) biaya pendidikan yang belum memadai untuk menunjang mutu pembelajaran.
Mutu pendidikan meliputi mutu input, proses, output, dan outcome. Input pendidikan dinyatakan bermutu jika siap berproses. Proses pendidikan bermutu apabila mampu menciptakan suasana yang PAIKEM ( Pembelajaran yang Aktif, Inovatif, Kreatif, Efektif, dan Menyenangkan). Output dinyatakan bermutu jika hasil belajar akademik dan nonakademik siswa tinggi. Outcome dinyatakan bermutu apabila lulusan cepat terserap didunia kerja dan semua pihak mengakui kehebatan lulusan. Disamping itu juga perlu diperhatikan tentang kualifikasi dan kompetensi guru. Rendahnya mutu pendidikan dapat menghambat penyediaan sumber daya manusia yang mempunyai keahlian dan keterampilan untuk memenuhi pembangunan bangsa di berbagai bidang. Sagala (2010:63) menyatakan bahwa pembelajaran mempunyai dua karakteristik, yaitu: (1) Dalam proses pembelajaran melibatkan proses berfikir; (2) Dalam proses pembelajaran membangun suasana 


\section{Jurnal Serunai Administrasi Pendidikan \\ Vol 8, No. 1, Februari 2019 \\ e-ISSN 2620-9209}

dialogis dan proses tanya jawab terus menerus diarahkan untuk memperbaiki dan meningkatkan kemampuan dan berfikir siswa, yang pada gilirannya kemampuan berfikir itu dapat membantu siswa untuk memperoleh pengetahuan yang mereka konstruksi sendiri. Hal ini senada dengan pendapat Shaleh (2005:220) bahwa pembelajaran yang efektif dan menyenangkan adalah pembelajaran yang dapat membawa siswa aktif belajar dan berlangsung secara efektif dalam lingkungan kondusif untuk belajar.

Menurut Juran dalam Arcaro (2005:9) tentang mutu adalah: (1) Meraih mutu merupakan proses yang tidak mengenal akhir. (2) Perbaikan mutu merupakan proses berkesinambungan, bukan program sekali jalan. (3) Mutu memerlukan kepemimpinan dari anggota dewan sekolah dan administrator. (4) Pelatihan massal merupakan prasyarat mutu. (6) Setiap orang di sekolah mesti mendapat pelatihan. Menurut Shaleh (2005:223) agar tercipta proses pembelajaran yang efektif dan efisien guru perlu mempertimbangkan secara strategis agar dapat diwujudkan situasi yang kondusif yang memungkinkan proses interaksi berlangsung dengan baik. Dalam situasi yang demikian perlu diupayakan agar: (1) siswa senantiasa menaruh minat dan perhatian; (2) siswa turut serta secara aktif dalam pengalaman belajar; (3) guru memberikan pengalaman yang terpadu dalam proses belajar; dan (4) timbulnya dorongan yang positif pada diri siswa untuk belajar.

Suyitno (2004:1) menyatakan bahwa pembelajaran merupakan upaya untuk menciptakan iklim dan pelayanan terhadap kemampuan, potensi, minat, bakat, dan kebutuhan peserta didik yang beragam agar terjadi interaksi optimal antara guru dengan siswa serta antara siswa dengan siswa. Pembelajaran menurut Hamalik (2003:57) merupakan proses perpaduan atau kombinasi dari unsur manusia, material, fasilitas, perlengkapan, dan prosedur. Disamping itu, Shaleh (2005:217) mendefinisikan bahwa pembelajaran adalah upaya guru agar terjadi peristiwa belajar yang dilakukan oleh siswa.

Keberhasilan kepala sekolah dalam menjalankan tugasnya dipengaruhi oleh gaya kepemimpinannya. Sehingga gaya kepemimpinan merupakan rangkaian kegiatan penataan yang diwujudkan sebagai kemampuan memengaruhi perilaku anggota organisasi dalam situasi tertentu agar bersedia bekerjasama untuk mencapai tujuan yang disepakati. Oleh karena itu gaya kepemimpinan kepala sekolah merupakan faktor penting dalam meningkatkan mutu pembelajaran.

Diantara empat belas prinsip Deming dalam meningkatkan mutu adalah melembagakan kepemimpinan. Mutu tak mungkin dihasilkan oleh kepemimpinan yang tak bermutu. Kepemimpinan disebut bermutu apabila mampu menggerakkan seluruh sistem secara terpadu sesuai dengan visi, misi dan prinsip yang telah ditentukan. Menurut Sagala (2009:170) mutu sekolah dalam pelayanan pendidikan dipandang dari kemampuannya memuaskan kebutuhan yang diharapkan. Sedangkan Sukmadinata (2006:20) mengatakan bahwa dalam meningkatkan mutu pendidikan harus menekankan pada pembelajaran siswa aktif dan bermakna.

Peningkatan mutu pendidikan nasional telah dilakukan dengan perbaikan kurikulum, 


\section{Jurnal Serunai Administrasi Pendidikan \\ Vol 8, No. 1, Februari 2019}

e-ISSN 2620-9209

peningkatan mutu guru, penyediaan sarana prasarana, perbaikan kesejahteraan guru, perbaikan manajemen, pengawasan dan perundang-undangan. Semua hal penting yang dilakukan pemerintah itu karena pendidikan terkait dengan peningkatan mutu sumber daya manusia (SDM) bangsa Indonesia yang kompeten dalam menghadapi perkembangan teknologi dan kemajuan zaman. Perkembangan teknologi dan kemajuan zaman yang terus terjadi mengharuskan setiap individu mampu bertahan hidup dan bersaing dalam kemajuan tersebut. Pendidikan merupakan upaya pengembangan kemampuan dan kepribadian yang mampu menjawab tantangan sesuai dengan perkembangan zaman yang sedang dan akan terjadi. Sesuai dengan fungsi dan tujuan Pendidikan Nasional yang tertuang dalam Undang-Undang No. 20 Tahun 2003 tentang Sistem Pendidikan Nasional (Pasal 3) bahwa Pendidikan Nasional berfungsi mengembangkan kemampuan dan membentuk watak serta peradaban bangsa yang bermanfaat dalam rangka mencerdaskan kehidupan bangsa, bertujuan untuk berkembangnya potensi peserta didik agar menjadi manusia yang beriman dan bertaqwa kepada Tuhan Yang Maha Esa, berakhlaq mulia, sehat, berilmu, cakap, kreatif, mandiri dan menjadi warga Negara yang demokratis serta bertanggung jawab.

Peran guru sangatlah menentukan dalam usaha peningkatan mutu pembelajaran. Guru yang profesional dalam mendidik peserta didiknya akan berupaya mengembangkan potensi yang ada pada peserta didik. Oleh sebab itu guru dituntut untuk mampu mendidik peserta didik dengan sebaikbaiknya. Armstrong (1981:34) mengungkapkan bahwa guru mempunyai tugas dan tanggung jawab pengajaran, tanggung jawab dalam memberikan bimbingan, mengembangkan profesi, mengembangkan kurikulum dan tanggung jawab membina hubungan dengan masyarakat.

Guru merupakan ujung tombak dalam penyelenggaraan pendidikan dan pengajaran disekolah. Guru bertanggung jawab dalam mengatur, mengarahkan dan menciptakan suasana yang kondusif bagi siswa untuk belajar. Ditangan guru terletak semua kegiatan pokok dalam proses belajar mengajar, seperti menentukan tujuan pembelajaran yang akan diberikan, memilih materi yang cocok dan sesuai dengan kemampuan siswa untuk mencapai tujuan yang telah dirumuskan, mempersiapkan strategi belajar yang tepat untuk mencapai tujuan, menciptakan situasi yang mendukung proses belajar mengajar yang kondusif dan mengevaluasi hasil belajar siswa. Kegiatankegiatan ini dapat berjalan dengan baik jika guru memiliki kemampuan dan sikap profesional.

Menurut Danim (2003:202) bahwa guru yang baik adalah mereka yang memiliki sifat kepemimpinan antara lain ditandai dengan kemampuannya bekerja dengan dan melalui orang lain, baik sesama staf maupun dengan siswa. Hanya guru yang memiliki sifat kepemimpinanlah yang mampu menjadi manajer kelas yang baik, dan dapat mengelola sumber-sumber belajar dan proses pembelajaran sendiri secara efektif dan efisien. Sedangkan menurut Kounin dalam Sopiatin (2010:48) guru dalam mengelola atau memanage kelas dapat juga memengaruhi perilaku siswa dalam melakukan proses belajar. Hal ini berarti bahwa jika seorang guru mengetahui dan 
melakukan manajemen kelas yang baik maka perilaku siswa akan baik dalam melakukan pembelajaran. Ini akan berdampak positif dalam hasil dan mutu pembelajaran.

Salah Satu faktor yang berhubungan dengan mutu pembelajaran adalah kepemimpinan. Kepemimpinan adalah suatu proses atas kemampuan memengaruhi orang lain melakukan kegiatan tertentu. Kepemimpinan mencakup konsep hubungan manusia yang luas. Dalam proses kepemimpinan terkandung interaksi tiga faktor penting yaitu fungsi pemimpin, pengikut (anggota) dan situasi yang melingkupi. Berarti dalam setiap situasi yang bagaimanapun kepemimpinan dapat berlangsung, baik itu di bidang pemerintahan, organisasi politik, bisnis, pendidikan, dan sebagainya. Menurut Thoha

(1986:45) kepemimpinan adalah kegiatan untuk memengaruhi perilaku orang lain, atau seni memengaruhi perilaku manusia baik perorangan maupun kelompok. Sedangkan Oteng (1983:253) mengatakan bahwa kepemimpinan adalah suatu kemampuan untuk menciptakan perubahan yang paling efektif atau proses memengaruhi seseorang atau kelompok dalam usaha pencapaian tujuan organisasi.

Hersey dan Blanchard

berpendapat kepemimpinan merupakan proses memengaruhi aktivitas individu atau kelompok dalam usaha kearah pencapaian tujuan dalam situasi tertentu. Dengan kata lain dalam kepemimpinan itu dijumpai fungsi pemimpin, pengikut (anggota) dan situasi. Stogdill dalam Keith Grint (1997:114) menjelaskan kepemimpinan adalah sebagai tindakan memengaruhi kegiatan kelompok dan pencapaian tujuan. Didalamnya terdiri dari unsur-unsur kelompok (dua orang atau lebih), ada tujuan dalam orientasi kegiatan serta pembagian tanggung jawab sebagai bentuk perbedaan kewajiban anggota. Berdasarkan latar belakang permasalahan di atas maka penulis menganggap penting membuat penelitian dengan judul "Hubungan Kepemimpinan Dengan Mutu Pembelajaran".

\section{B. Metode Penelitian}

Penelitian ini berbentuk penelitian korelasional. Penelitian korelasional dimaksudkan untuk mengetahui ada tidaknya hubungan antara dua variabel atau beberapa variabel. Menurut Arikunto (2004: 114) penelitian korelasi merupakan penelitian yang dimaksudkan untuk mengetahui ada tidaknya hubungan antara dua atau lebih variabel yang satu dengan variabel yang lain. Besar kecilnya hubungan tersebut dinyatakan dalam bentuk koefisien korelasi.

Menurut Sugiono (2009:117) populasi adalah wilayah generalisasi yang terdiri atas obyek/subyek yang mempunyai kualitas dan karakteristik tertentu yang ditetapkan oleh peneliti untuk di pelajari dan kemudian di tarik kesimpulannya. Populasi dalam penelitian ini adalah guru SMA Rayon 3 Medan yang berjumlah 67 orang guru. Sampel adalah sebahagian dari populasi, sampel dalam penelitian ini total populasi yaitu sebanyak 67 orang guru.

Data yang diperoleh dianalisis dengan menggunakan teknik statistik yakni uji persyaratan analisis data dan pengujian hipotesi. Dalam hal ini menggunakan bantuan komputer program SPSS 16. 


\section{HASIL PENELITIAN DAN PEMBAHASAN}

Berdasarkan butir-butir pernyataan variabel kepemimpinan yang berjumlah 20 butir, diperoleh skor terendah adalah 58 dan yang tertinggi adalah 90. Rata-rata 72,45, simpangan baku 8,51, median 75,82, dan modus 76,04. Sedangkan berdasarkan butir-butir pernyataan variabel mutu pembelajaran yang berjumlah 30 butir, maka skor terendah adalah 61 dan yang tertinggi adalah 99. Rata-rata 76,75, simpangan baku 10,19, median 78,71, dan modus 76,08. Hubungan kepemimpinan dengan mutu pembelajaran adalah 0,604, Hal ini berarti $60,4 \%$ mutu pembelajaran dapat dijelaskan oleh kepemimpinan. Koefisien determinasi ini juga signifikan secara statistik yang ditandai dengan nilai signifikansi sebesar 0,000 yang berada dibawah $\alpha$ sebesar 0,05 . Persamaan regresi yang diperoleh adalah $\mathrm{Y}=9,46+1,19 \mathrm{X}$. Hal ini berarti kenaikan 1 satuan pada kepemimpinan akan meningkatkan mutu pembelajaran sebesar 1,19. Model ini juga signifikan secara statistik yang ditandai dengan nilai signifikansi hitung 0,000 berada dibawah $\alpha$ sebesar 0,05 .

Hal ini sejalan dengan pendapat Deming dalam meningkatkan mutu adalah melembagakan kepemimpinan. Mutu tak mungkin dihasilkan oleh kepemimpinan yang tak bermutu. Kepemimpinan disebut bermutu apabila mampu menggerakkan seluruh sistem secara terpadu sesuai dengan visi, misi dan prinsip yang telah ditentukan. Kepala sekolah merupakan faktor kunci efektif tidaknya suatu sekolah. Dikatakan faktor kunci karena kepala sekolah memainkan peranan yang sangat penting pada keseluruhan aspek pengelolaan sekolah. Sebagai manajer pendidikan yang profesional, kepala sekolah bertanggung jawab sepenuhnya terhadap sukses atau tidaknya sekolah yang dipimpinnya. Menurut Danim (2003:217) kepala sekolah adalah orang yang paling bertanggung jawab untuk memotivasi guru dalam mencapai tujuan yang dikehendaki dengan memecahkan berbagai tantangan yang dihadapi. Kegagalan kepala sekolah dalam memerankan fungsinya akan menyebabkan lembaga yang dipimpinnya akan masuk kedalam jurang yang dalam.

Temuan penelitian menunjukkan bahwa ada hubungan yang signifikan antara kepemimpinan dengan mutu pembelajaran sebesar $60,4 \%$. Temuan ini didukung pendapat Juran dalam Arcaro (2005:9) tentang mutu adalah: (1) Meraih mutu merupakan proses yang tidak mengenal akhir; (2) Perbaikan mutu merupakan proses berkesinambungan, bukan program sekali jalan; (3) Mutu memerlukan kepemimpinan dari anggota dewan sekolah dan administrator; (4) Pelatihan massal merupakan prasyarat mutu; dan (6) Setiap orang di sekolah mesti mendapat pelatihan. Kepemimpinan dari anggota dewan sekolah disini adalah kepala sekolah.

Keberhasilan kepala sekolah dalam menjalankan tugasnya dipengaruhi oleh kepemimpinannya. Sehingga kepemimpinan merupakan rangkaian kegiatan penataan yang diwujudkan sebagai kemampuan memengaruhi perilaku anggota organisasi dalam situasi tertentu agar bersedia bekerjasama untuk mencapai tujuan yang disepakati. Oleh karena itu kepemimpinan merupakan salah satu faktor penting dalam 


\section{Jurnal Serunai Administrasi Pendidikan \\ Vol 8, No. 1, Februari 2019}

e-ISSN 2620-9209

meningkatkan mutu pembelajaran. Menurut Rivai dalam Nurjannah (2008:21) mengemukakan bahwa kepemimpinan adalah pola menyeluruh dari tindakan seorang pemimpin, baik yang tampak maupun yang tidak tampak oleh bawahannya. Kepemimpinan menggambarkan kombinasi yang konsisten dari falsafah, keterampilan, sifat, dan sikap yang mendasari perilaku seseorang. Kepemimpinan menunjukkan secara langsung maupun tidak langsung tentang keyakinan seorang pemimpin terhadap kemampuan bawahannya. Artinya, kepemimpinan adalah perilaku dan strategi sebagai hasil kombinasi dari falsafah, keterampilan, sifat, sikap yang sering diterapkan seorang pemimpin ketika ia mencoba memengaruhi kinerja bawahannya.

Guru cenderung akan termotivasi dalam meningkatkan mutu pembelajaran jika kepala sekolah: (1) memiliki sifat komunikatif dengan bawahan, selalu memberikan pujian atas keberhasilan tugas bawahan; (2) disiplin; (3) mengharapkan bawahan dapat mencapai tujuan secara maksimal dan efektif; dan (4) selalu memberikan peluang kepada bawahan untuk dapat meningkatkan prestasi baik di sekolah maupun di luar sekolah. Semua point di atas merupakan sebahagian indikator dari gaya kepemimpinan partisipatif dan gaya kepemimpinan berorientasi pada prestasi.

Temuan penelitian ini juga didukung oleh hasil penelitian Bambang Budi Wiyono (2000) yang meneliti tentang Gaya Kepemimpinan Kepala Sekolah Dan Semangat Kerja Guru dalam Melaksanakan Tugas Jabatan di Sekolah Dasar Negeri Kabupaten Bantul. Hasil penelitian disimpulkan bahwa banyak Kepala Sekolah yang memiliki gaya kepemimpinan yang berorientasi tinggi pada hubungan manusia dan paling sedikit yang memiliki gaya kepemimpinan yang berorientasi rendah terhadap tugas ataupun hubungan manusia.

Temuan-temuan penelitian lain tentang gaya kepemimpinan kepala sekolah mengatakan bahwa gaya kepemimpinan kepala sekolah memainkan peranan penting dalam keseluruhan upaya untuk mewujudkan efektifitas dan mutu sekolah. Austin dalam Danim (2003:217) yang meneliti semua kepala sekolah di negara bagian Maryland, Amerika Serikat menyatakan bahwa perbedaan antara sekolah yang berprestasi tinggi dan yang berprestasi rendah di sebabkan oleh adanya pengaruh gaya kepemimpinan kepala sekolah. Ruth Love dalam Danim (2003:217) juga menyatakan I never seen a good school without a good principals. Saya tidak pernah melihat sekolah yang baik tanpa kepala sekolah yang baik.

\section{Penutup}

Berdasarkan data dan hasil analisis yang telah dipaparkan diatas, dapat ditarik kesimpulkan sebagai berikut: Terdapat hubungan yang signifikan dan berarti antara gaya kepemimpinan kepala sekolah dengan mutu pembelajaran. Koefisien Korelasi yang diperoleh adalah 0,604. Hal ini mengindikasikan betapa pentingnya kepemimpinan dalam meningkatkan mutu pembelajaran. Berdasarkan temuan penelitian dapat disimpulkan bahwa hipotesis penelitian yang menyatakan ada hubungan antara kepemimpinan 
dengan mutu pembelajaran dapat diterima.

Saran-saran yang disampaikan sehubungan dengan temuan penelitian ini adalah sebagai berikut: Pertama, melaksanakan berbagai pelatihan untuk meningkatkan pengetahuan dan pemahaman guru tentang manajemen kelas, hal ini mengingat berdasarkan hasil penelitian ini aspek pengetahuan manajemen kelas masih perlu ditingkatkan. Kedua, bagi kepala sekolah, perlu melakukan pembenahan terhadap kepemimpinannya, kepala sekolah diminta cenderung menggunakan gaya kepemimpinan yang berorientasi pada manusia dan memperkecil gaya yang berorientasi pada tugas. Ketiga, memberikan reward kepada para guru yang berprestasi dalam melaksanakan tugasnya, hal ini akan memberikan stimulan bagi guru yang lain untuk mau berpacu meningkatkan prestasi dalam melaksanakan tugas.

\section{DAFTAR PUSTAKA}

Amstrong, Michael. 1981. A Hand Book of Human Resources management. Jakarta : Gramedia.

Arcaro, Jerome.S. 2005. Pendidikan Berbasis Mutu: Prinsip-Prinsip Perumusan dan Tata Langkah Penerapan. Terjemahan Yosal Iriantara. Yogyakarta : Pustaka Pelajar Offset.

Arikunto, Suharsimi. 2004. Evaluasi Program Pendidikan. Pedoman Teoritis Praktis Bagi Praktisi Pendidikan. Jakarta : Bumi Aksara.

Arikunto, Suharsimi., Suhardjono, Supardi. 2006. Penelitian Tindakan Kelas. Jakarta : Bumi Aksara.

Devi, Poppy Kamalia,dkk. 2009. Modul BERMUTU (Better Education through Reformed Management and Universal Teacher Upgrading). P4TK : Bandung.
Hersey, Paul \& Blanchard, H Kenneth. 1988. Management of Organizational Behaviour. New Jersey : Englewood Cliffs.

Daniel,Goleman., Boyatzis, McKee. 2007. Kepemimpinan Berdasarkan Kecerdasan Emosi. Jakarta : Gramedia Pustaka Utama.

Danil, Muhammad. 2008. Kontribusi Kepemimpinan Kepala Sekolah dan Iklim Sekolah Terhadap Kompetensi Guru MTs.N di Kabupaten Tanah Datar. Tesis : UNP Padang.

Danim, Sudarwan. 2003. Menjadi Komunitas Pembelajar. Kepemimpinan Transformasional dalam Komunitas Organisasi Pembelajar. Jakarta : Bumi Aksara. . 2007. Visi Baru Manajemen Sekolah. Jakarta : Bumi Aksara.

Esti, Wuryani. 2002. Psikologi Pendidikan. Jakarta : Grasindo

Grint, Keith. 1997. Leadership: Classical, Contemporary, and Critical Approach. New York : Oxford University.

Hamalik, Oemar. 2003. Proses Belajar mengajar. Jakarta : Bumi Aksara.

Handayaningrat, Soewarno.1996. Pengantar Studi Ilmu Administrasi dan Manajemen. Jakarta : Gunung Agung.

Hayat, Bahrul \& Yusuf, Suhendra. 2009. Banchmarking Internasional Mutu Pendidikan. Jakarta : Bumi Aksara.

Isaac, Stephen \& Michael, William. 1982. Handbook in Research and Evaluation. California : Edits publishers

Kamars, Dachnel. 2005. Administrasi Pendidikan Teori dan Praktek. Padang : Universitas Putra Indonesia Press.

Kartono, Kartini. 1980. Pemimpin Dan kepemimpinan. Jakarta : Raja Grafindo Persada 
Kast, Remont E. 1990. Organisasi Dan Manajemen. Jakarta : Bumi Aksara

Le Clear. 2005. Relationship Among Leadership Style, School Culture, and Student Achievement. A Dissertation Presented to The Graduate School of The University of Florida In Partial Fulfillment of The Requirements For The Degree of Doctor of Education, University of Florida. http://etd.fcla.edu/UF/UFE0013022/leclear.

Locke, E.A. 1997. Esensi Kepemimpinan. Terjemahan Aris Ananday. Jakarta : Spektum

Luffi, Mampa. 2010. Hubungan Antara Manajemen Kelas Dan Pelaksanaan Layanan Bimbingan Konseling Dengan Mutu pembelajaran di SMPN se Kec. Medan Barat. Tesis : PPs Unimed.

Monday, R.W. and Premeaux, SH. 1995. Management : Concepts Practice and Skill. New Jersey : Prentice Hall Inc. Englewood Cliffs.

Mulyasa, E. 2007. Menjadi Kepala Sekolah yang Profesional. Bandung : Remaja Rosdakarya.

Nawawi, Hadari. 2000. Organisasi Sekolah dan Pengelolaan Kelas. Jakarta : Gunung Agung

Oteng, Sutisna. 1983. Administrasi Pendidikan Dasar Teoritis Untuk Praktek Profesional. Bandung : Angkasa.

Pasolong, Harbani. 2008. Kepemimpinan Birokrasi. Bandung : Alfabeta.

Pidatta, Made. 1997. Pengelolaan Kelas. Surabaya : Usaha nasional.

Ramly, Nadjamuddin. 2005. Membangun Pendidikan yang memberdayakan dan Mencerahkan. Jakarta : Grafindo.

Reeser. 1973. Management Function And Modern Concepts. Illionis : Scoot Foresman and Company
Sagala, Syaiful. 2006. Administrasi pendidikan Kontemporer. Bandung : Alfabeta

2009. Manajemen Strategik Dalam Peningkatan Mutu pendidikan. Bandung : Alfabeta.

2009. Kemampuan Profesional Guru dan Tenaga Kependidikan. Bandung : Alfabeta

2010. Supervisi Pembelajaran. Bandung : Alfabeta

Sallis, Edward. 2006. Total Quality Management In Education. Terjemahan Ahmad Ali Riyadi. Jogjakarta : IRCiSoD.

Santoso, Singgih. 2005. Buku Latihan SPSS Statistik Multivariat. Jakarta : Gramedia.

Shaleh, Abdul R. 2005. Madrasah dan Pendidikan Anak Bangsa. Jakarta : Raja Grafindo Persada.

Sukmadinata. 2006. Pengendalian Mutu Pendidikan Sekolah Menengah. Bandung: Refika Aditama

Sudjana, Nana. 1986. Metode Statistika. Bandung : Tarsita

Sudijono, Anas. 2008. Pengantar Evaluasi Pendidikan, Jakarta : PT. Raja Grafindo Persada

Somantri, A dan Muhidin, S.A. 2006. Aplikasi Statistik Dalam Penelitian, Bandung: Pustaka Sari.

Sugiono. 2009. Metode Penelitian Pendidikan. Bandung : Alfabeta.

Sumayang, Lalu. 2003. Manajemen Produksi dan Operasi. Jakarta : Salemba Empat.

Surapranata, Sumarna. 2005. Analisis, Validitas, Reliabilitas, dan Interpretasi Hasil Tes. Bandung : Remaja Rosdakarya

Sutopo. 1999. Administrasi, Manajemen dan Organisasi. Jakarta : LAN-RI 
Suyitno, Amin. 2004. Pemilihan Model-Model Pembelajaran dan Penerapannya di Sekolah. Semarang : FMIPA UNNES.

Sopiatin, Popi. 2010. Manajemen Belajar Berbasis kepuasan Siswa. Jakarta : Ghalia Indonesia.

ISyafaruddin. 2005. Manajemen Mutu Pembelajaran. Ciputat : Quantum Teaching.

Terry, George R. 1973. The Principles of Management. Illionis.

Thoha, Miftah. 1986. Pemimpin dan Kepemimpinan. Jakarta : Rineka Cipta 1989. Perilaku Organisasi. Jakarta : Persada Cipta.

Tim Penyusun KBBI. 1991. Kamus Besar Bahasa Indonesia. Jakarta : Balai Pustaka.

Toenlioe, A.J. 1992. Teori dan Praktek Pengelolaan Kelas. Bandung : Usaha Nasional.

Usman, H \& Akbar, P.S. 2008. Pengantar Statistik. Jakarta : Bumi Aksara.

Wang, F.J., Shieh, C.J. and Tang,M.L. 2010. Effect of Leadership Style on Organizational Performace as Viewed from Human Resource Management Strategy. African Journal of Business Management. Vol 4(18), pp.39243936, 18 December 2010. ISSN 19938233@2010 Academic Journals. http://academicjournals.org/ajbm/PDF/pdf20 10/18Dec/Wang_e_al_2.

Winardi. 1990. Asas-asas manajemen. Bandung : Mandar maju.

2005. Manajemen Perilaku Organisasi. Jakarta : kencana.

Wiyono, Bambang Budi. 2000. Gaya Kepemimpinan Kepala Sekolah dan Semangat Kerja Guru dalam Melaksanakan Tugas jabatan di Sekolah Dasar. Tesis : Universitas Negeri Malang.
Wong, Harry. 2000. Effective Classroom Management. San Diego : Carreva

Wragg, E.C. 1996. Pengelolaan Kelas. Terjemahan Anwar Jasin. Jakarta : Grasindo

Zamroni. 2007. Meningkatkan Mutu Sekolah. Jakarta : PSAP Muhammadiyah. 